\title{
Soil bacterial community structure and functional responses across a long- term mineral phosphorus (Pi) fertilisation gradient differ in grazed and cut grasslands
}

\author{
Kate Randall $^{\mathrm{a}, \mathrm{b}, *}$, Fiona Brennan ${ }^{\mathrm{c}}$, Nicholas Clipson ${ }^{\mathrm{a}}$, Rachel Creamer ${ }^{\mathrm{c}, \mathrm{d}}$, Bryan Griffiths ${ }^{\mathrm{c}, \mathrm{e}}$, \\ Sean Storey ${ }^{a}$, Evelyn Doyle ${ }^{a}$ \\ ${ }^{a}$ School of Biology and Environmental Science, Earth Institute, University College Dublin, Dublin 4, Ireland \\ ${ }^{\mathrm{b}}$ School of Biological Sciences, University of Essex, Wivenhoe Park, Colchester CO4 3SQ, UK \\ ${ }^{\mathrm{c}}$ Teagasc Environmental Research Centre, Johnstown Castle, Wexford, Ireland \\ ${ }^{\mathrm{d}}$ Soil Biology Group, Wageningen University and Research, the Netherlands. \\ ${ }^{\mathrm{e}}$ SRUC, Crop and Soil Systems Research Group, West Mains Road, Edinburgh EH9 3JG, UK
}

\section{A R T I C L E I N F O}

\section{Keywords:}

Agricultural management

Bacteria

Grassland

Phosphorus

Soil

\begin{abstract}
A B S T R A C T
Grasslands form a significant proportion of land used across the globe and future management is important. The objective of this study was to compare the long-term impact of inorganic phosphorus (Pi) fertilisation rates (P0, P15 and P30 ha ${ }^{-1} \mathrm{yr}^{-1}$ ) under two grass management trials (grazed vs. cut and removed) on soil physicochemical properties, microbial biomass, phosphomonoesterase activity, bacterial community structure and abundance of a phosphorus (P) mineralising gene ( $p h o D)$. Under grazing, microbial biomass and soil phosphorus concentrations (total and $\mathrm{Pi}$ ) generally increased with Pi fertilisation rate, accompanied by significant differences in bacterial community structure between unfertilised (P0) and P30 soil. At the cut and removed site, although Pi was significantly greater in P30 soil, P concentrations (total and Pi) did not increase to the same extent as for grazing, with microbial biomass and bacterial community structures unresponsive to Pi fertilisation. Despite differences in soil P concentrations (total and Pi) and microbial biomass between sites, the abundance of bacterial phoD increased with increasing soil Pi across both sites, while phosphomonoesterase activity decreased. Amplicon sequencing revealed Acidobacteria were the dominant bacterial phylum across both grasslands, but significant differences in relative abundances of bacterial genera were detected at the grazed site only. The bacterial genera Gp6 and Gp16 increased significantly with $\mathrm{Pi}$ fertilisation under grazing. Conversely, Bradyrhizobium as well as unclassified genus-type groups belonging to Actinobacteria and Acidimicrobiales significantly decreased with Pi fertilisation, suggesting potential roles in P mobilisation when soil Pi concentrations are low. This study highlights the importance of long-term Pi fertilisation rates and aboveground vegetation removal in shaping soil bacterial community structure and microbial biomass, which in turn may impact soil fertility and plant productivity within agricultural soils.
\end{abstract}

\section{Introduction}

Grasslands are the second largest terrestrial biome on the planet, comprising 37\% of available soil (excluding Antarctica and Greenland) (FAO, 2010; O'Mara, 2012). They provide key services such as the production of food crops and meat. They contribute to the provision of clean water and flood prevention and are essential for carbon sequestration (FAO, 2015). With the current world population of 7.6 billion projected to reach 9.8 billion by 2050 (UN, 2017), there is considerable focus on improving productivity from grasslands to ensure food security. The management of grasslands has steadily intensified across Europe (Isselstein et al., 2005) and typically involves combinations of increased fertilisation, sward cutting (Lemanski and Scheu, 2015) and grazing (Shange et al., 2012; De Vries et al., 2015).

Efficient and sustainable fertilisation of agricultural soils is a significant challenge, and until alternative methods match productivity

\footnotetext{
Abbreviations: DW, dry weight; Pi, inorganic phosphorus; Soil WHC, soil water holding capacity

* Corresponding author at: School of Biology and Environmental Science, Earth Institute, University College Dublin, Dublin 4, Ireland

E-mail addresses: kate.randall@essex.ac.uk (K. Randall), fiona.brennan@teagasc.ie (F. Brennan), Nicholas.clipson@ucd.ie (N. Clipson), rachel.creamer@wur.nl (R. Creamer), Bryan.Griffiths@sruc.ac.uk (B. Griffiths), sean.storey@ucd.ie (S. Storey), evelyn.doyle@ucd.ie (E. Doyle).
} 
levels, additions of mineral fertilisers to soil will remain necessary (Tilman et al., 2002). Mineral/inorganic phosphorus (Pi) fertilisation is a particular concern for agriculture, as the main resource in Pi fertiliser production is finite (Richardson and Simpson, 2011; Simpson et al., 2011). As demand increases and stocks deplete, considerable interest has focussed on improving phosphorus (P) use efficiency within agriculture (Gorazda et al., 2013; Sharma et al., 2013; Dotaniya and Meena, 2014).

Water soluble inorganic phosphorus (Pi) is the primary form in which plants and microorganisms take up P. Organic $\mathrm{P}$ is however the dominant form in temperate grassland soils (Liebisch et al., 2014; Stutter, 2015), ranging between 20 and $80 \%$ of the total soil P (Sharma et al., 2013). The high reactivity of phosphate ions in soil means concentrations of Pi available for uptake are generally low, at $<1 \%$ of the total P (Sims and Sharpley, 2005; Sharma et al., 2013), often resulting in $\mathrm{P}$ as the growth limiting nutrient for plants (Sharma et al., 2013). To compensate for this, over-fertilisation was common practice. A need to reduce pollution however led to European legislation (COM 91/676/ EEC, 1991; COM 2000/60/EC, 2000) that now regulates fertilisation rates across Europe. This has boosted efforts to find alternative methods for increasing concentrations of available Pi in soil.

Microorganisms are key drivers of $\mathrm{P}$ cycling within the terrestrial environment. The mechanisms used can be broadly classified as inorganic P solubilisation, or organic P mineralisation. Microbial inorganic $\mathrm{P}$ solubilisation occurs primarily through release of organic anions which causes precipitated P-metal complexes to solubilise, releasing Pi (Osorio and Habte, 2013; Sharma et al., 2013). Bacteria capable of this mode of solubilisation include members of the Pseudomonadaceae, Rhizobiaceae, Caulobacteraceau, Comamonadaceae, Burkholderiaceae, Enterobacteriaceae within the Proteobacteria (Mander et al., 2012), and representatives of the phylum Actinobacteria (Mander et al., 2012; Wakelin et al., 2012). Organic P mineralisation is the breakdown of organic P compounds to eventually release of Pi. Within soil this is catalysed by a broad group of enzymes called phosphatases, with phosphomonoesterases (EC 3.13.2) particularly important as they hydrolyse monoester bonds and release Pi. Microbial phosphate mineralisation has been observed by organisms belonging to $\alpha$ - and $\gamma$ Proteobacteria, the Actinobacteria (Tan et al., 2013), Actinomycetales, Bacilliales, Gloeobacterales, Planctomycetales and Rhizobiales (Ragot et al., 2016). In addition, some microorganisms improve plant $P$ uptake indirectly by modifying root systems and forming symbioses with plants (Richardson and Simpson, 2011).

Understanding how soil microorganisms respond to Pi fertilisation within agricultural systems could develop fertiliser regimes less reliant upon Pi fertiliser inputs (Owen et al., 2015). However, the complexity of $\mathrm{P}$ cycling pathways means studies focussing on microbial P cycling have lagged behind those of carbon (C) and nitrogen (N). Molecular biomarkers to target microbial groups associated with $\mathrm{P}$ cycling typically focus on organic P mineralisation and phosphatases (Kageyama et al., 2011; Tan et al., 2013; Fraser et al., 2015; Acuña et al., 2016; Ragot et al., 2016), with many studies targeting bacterial alkaline phosphatases (Fraser et al., 2015; Chhabra et al., 2013; Tan et al., 2013). Three gene families encode for bacterial alkaline phosphatases (phoD, phoX and phoA). Although all three families have been identified in environmental samples, $p h o D$ has been found to dominate metagenomic datasets from soil environments (Tan et al., 2013). To-date most research on microbial P cycling has focussed on aquatic environments, with $p h o D$ being the most common biomarker. Although there are a number of studies profiling soil microbial responses to a variety of $\mathrm{P}$ fertilisation treatments across a range of management scenarios (Azziz et al., 2012; Osorio and Habte, 2013; Sharma et al., 2013; Tan et al., 2013; Chen et al., 2014), most have used exaggerated application rates (Wakelin et al., 2012), compared inorganic and organic P amendments (Fraser et al., 2015), compared single Pi rates to unfertilised controls, or use combined $\mathrm{N}$ and $\mathrm{P}$ regimes (Ragot et al., 2016). Comparisons across Pi fertilisation gradients typical for rain fed temperate grasslands are lacking.

Land management practices other than fertilisation have been shown to impact nutrient levels in soil (Jangid et al., 2008; Keith et al., 2012; Neal et al., 2017). Although grazing and cutting both remove aboveground vegetation, grazing generates a significant pathway of nutrient re-introduction belowground that cutting and removing vegetation does not (Rumpel et al., 2015). Most N and P ingested by grazing mammals is returned to soil via excreta (Parsons et al., 2013). For $\mathrm{N}$ and $\mathrm{P}$, this can equate to $65 \mathrm{~N} \mathrm{~kg} \mathrm{yr}^{-1}$ and $13 \mathrm{P} \mathrm{kg} \mathrm{yr}^{-1}$ for a mature cow (EU, 2014), whereas $30 \%$ of ingested $C$ is returned to soil this way, with $70 \%$ lost via $\mathrm{CO}_{2}$ and $\mathrm{CH}_{4}$ production (Parsons et al., 2013). The effects of cutting and removing aboveground vegetation is relatively understudied in grassland systems compared to other aboveground grassland management approaches (Poeplau et al., 2016). Lower rates of C sequestration have been observed in cut and removed systems compared to grazing (Fitter et al., 1997; Hungate et al., 1997; Nitschelm et al., 1997), but grazing effects on soil organic C within grassland soils can vary depending on context (McSherry and Ritchie, 2013; Abdalla et al., 2018). When considering the importance of grazing, cutting and fertilisation regimes in grassland management, an understanding of how the soil environment responds to combined long-term management is unclear.

The aim of the current study was to determine the effect of longterm Pi fertilisation on soil properties and specifically bacterial communities in two adjacent grassland soils which differed in terms of aboveground management (grazed vs. cut and removed). The grazed site (G) was rotationally grazed by cattle, whilst the cut and removed site (C) had the aboveground vegetation removed. Both sites had a long history of defined Pi fertilisation, receiving one of the following applications of calcium superphosphate: unfertilised (P0), 15 (P15) or 30 (P30) $\mathrm{kg} \mathrm{ha}^{-1} \mathrm{yr}^{-1}$. At the time of sampling, the grazed trial had been established for 45 years, and the cut trial for 18 years. Soil physicochemical properties, microbial biomass, phosphomonoesterase activity, bacterial community structure and bacterial phoD copy numbers were examined at both sites to determine if Pi fertilisation rate would increase soil $\mathrm{P}$ ( $\mathrm{Pi}$ and total $\mathrm{P}$ ), microbial biomass and potential $\mathrm{P}$ cycling ability, as well as harbour different bacterial community structures in a similar manner under both aboveground regimes.

\section{Materials and methods}

\subsection{Site descriptions}

Both grassland field sites are located in Co. Wexford, Ireland: grazed $52^{\circ} 16^{\prime} \mathrm{N}, 06^{\circ} 30^{\prime} \mathrm{W}$ (Tunney et al., 2010) and cut $52^{\circ} 17^{\prime} \mathrm{N}, 06^{\circ} 30^{\prime} \mathrm{W}$ (Daly and Casey, 2006).

Grazed site (G) - A detailed description of the grazed site has been previously published (Culleton et al., 2002; King-Salter, 2008; Griffiths et al., 2012; Chen et al., 2014). Established in 1968 on a Humic Gleysol soil (IUSS WRB, 2015), the soil was initially sown with Lolium perenne and divided into thirty-six 0.45 ha plots, twelve per Pi fertilisation rate (G-P0, G-P15, G-P30 $\mathrm{kg} \mathrm{ha}^{-1} \mathrm{yr}^{-1}$ ), along with $\mathrm{N}$ (ammonium nitrate $250 \mathrm{~kg} \mathrm{ha}^{-1} \mathrm{yr}^{-1}$ ) and $\mathrm{K}$ (potassium chloride $20 \mathrm{~kg} \mathrm{ha}^{-1}$ ). After 1999, a consistent grazing stocking rate was applied $\left(3300 \mathrm{~kg}\right.$ stock ha $\left.{ }^{-1}\right)$ and $\mathrm{Pi}$ fertilisation rates were altered to assess recovery responses to $\mathrm{Pi}$ fertilisation (SI Fig. 1). No legacy effect due to previous variation in stocking rates was detected across the site (Tunney et al., 2010). For the purpose of this study, only plots receiving continual $\mathrm{Pi}$ applications of 0 (G-P0), 15 (G-P15) or 30 (G-P30) kg Pi ha ${ }^{-1} \mathrm{yr}^{-1}$ since 1968 were sampled (SI Fig. 1).

Cut and removed site (C) - The cut site was established in February 1995 on a loam textured soil and divided into sixteen plots $(10 \times 2 \mathrm{~m})$ in a fully randomised block design (Massey, 2012) (SI Fig. 2). Each Pi treatment had four replicate plots receiving $16 \%$ superphosphate at fertilisation rates of 0 (C-P0), $15(\mathrm{C}-\mathrm{P} 15), 30(\mathrm{C}-\mathrm{P} 30)$ and $45(\mathrm{P}-45)$ $\mathrm{kg} \mathrm{Pi} \mathrm{ha}^{-1} \mathrm{yr}^{-1}$ each February. Only plots receiving 0 (C-P0), 15 
(C-P15) and 30 (C-P30) $\mathrm{kg} \mathrm{Pi} \mathrm{ha}^{-1} \mathrm{yr}^{-1}$ were sampled to relate to the grazed site. Aboveground plant biomass at this site was cut eight times per year to a height of $5 / 6 \mathrm{~cm}$ using a plot harvester (Massey et al., 2015). All cuttings were removed. After each harvest, all plots received $\mathrm{N}$ (calcium ammonium nitrate, $40 \mathrm{~kg} \mathrm{Nha}^{-1}$ ) and $\mathrm{K}$ (potassium chloride, $125 \mathrm{~kg} \mathrm{~K} \mathrm{ha}^{-1} \mathrm{yr}^{-1}$ ), at rates to compensate for the removal of these nutrients by harvesting.

\subsection{Sample collection}

In October 2013, three plots per Pi fertilisation treatment (P0, P15 or P30) were sampled at both sites. For each of the eighteen plots sampled, a composite sample was made using a Dutch auger $(4 \mathrm{~cm}$ diameter) by sieving $(<2 \mathrm{~mm})$. Sub-samples were stored at $-20^{\circ} \mathrm{C}$ for molecular analysis, with the remainder stored at $4{ }^{\circ} \mathrm{C}$ and processed for biochemical and physicochemical characterisation.

Total soil $\mathrm{C}$ and $\mathrm{N}$ were determined using an elemental analyser (LECO TrueSpec CN elemental analyser, US) from $0.2 \mathrm{~g}$ of ball milled soil dried at $40^{\circ} \mathrm{C}$ for $48 \mathrm{~h}$ as described by Griffiths et al. (2012). Total soil $\mathrm{P}$ was determined using microwave digestion (EPA, 2007) and measured via inductively coupled plasma (ICP) optical emission spectroscopy from $0.5 \mathrm{~g}$ of ball milled soil dried at $40^{\circ} \mathrm{C}$ for $48 \mathrm{~h}$. Available Pi was determined using the Morgan's extraction method (McCormack, 2002), as described by Massey (2012) and measured spectrophotometrically at $880 \mathrm{~nm}$ using the phosphomolybdate method (Murphy and Riley, 1962); inorganic N fractions within soil were determined by $2 \mathrm{M}$ potassium chloride extraction (Mulvaney, 1996) and analysed for $\mathrm{NO}_{3}{ }^{-}$and $\mathrm{NH}_{4}{ }^{+}$by colorimetric analysis using an Aquakem 600A (Konelab 60, US).

Soil $\mathrm{pH}$ was determined using a soil: deionised water ratio of 1:2 (w/v) (McCormack, 2002) measured using a WTW pH 526 pH meter (Labsource, US); $5 \mathrm{~g}$ of soil was oven dried at $105^{\circ} \mathrm{C}$ for $24 \mathrm{~h}$ to determine soil moisture content; soil water holding capacity (WHC) was determined from $50 \mathrm{~g}$ of fresh soil placed into a Haines funnel with $100 \mathrm{ml}$ deionised water added to the soil and covered. After $24 \mathrm{~h}$ water was drained for $30 \mathrm{~min}$ and the volume collected (Jenkinson and Powlson, 1976). Soil textural analysis was conducted following the methodology by Culleton (1972).

\subsection{Microbial biomass}

Microbial biomass C, N (Murphy and Riley, 1962) and P (Brookes et al., 1982) were measured using chloroform-fumigation extraction methods. Within the microbial biomass, total organic carbon (TOC) was measured by combustion (Baird, 2005) using a Shimadzu TOC-VCPH analyser with ASI-V autosampler; total organic nitrogen (TON) was determined by alkaline persulfate oxidation (Cabrera and Beare, 1993) and available Pi by the ammonium molybdate-ascorbic acid method (Watanabe and Olsen, 1965) using a Cary 50 Cone-UV spectrophotometer. Soil microbial biomass $\mathrm{C}, \mathrm{N}$ and $\mathrm{P}$ were calculated as the difference between the fumigated and un-fumigated samples using conversion factors of 0.45 for C (Wu et al., 1990), 0.45 for N (Jenkinson et al., 2004) and 0.40 for P (Hedley and Stewart, 1982). DOC and DON can both be calculated when determining the microbial biomass as the amount of $\mathrm{C}$ and $\mathrm{N}$ in un-fumigated samples (Griffiths et al., 2012).

\subsection{Acid phosphomonoesterase activity}

Acid phosphomonoesterase (EC 3.13.2) activity was determined using a modified method of Tabatabai and Bremner (1969), with toluene step removed. Optical density of the supernatant was measured at $400 \mathrm{~nm}$ using a spectrophotometer (Helios Unicam). Phosphomonoesterase activity was calculated with respect to standard curves constructed using known concentrations of p-nitrophenol and expressed as $\mu$ g PNP $\mathrm{g}^{-1}$ DW soil $\mathrm{h}^{-1}$.

\subsection{Soil DNA extraction}

DNA was extracted from $0.5 \mathrm{~g}$ of soil in triplicate per plot using a modified version of the method published by Griffiths et al. (2000) (Storey et al., 2014). Extracts were quantified and quality checked using a Nanodrop ND-1000 Spectrophotometer (ThermoFisher, UK) and further cleaned using High Pure PCR product purification kit (Roche, UK) to ensure maximal removal of PCR inhibitors.

\subsection{Amplicon sequencing of bacterial community}

Next generation sequencing of the bacterial $16 S$ rRNA gene was performed using a modified protocol of Kozich et al. (2013). The forward (5'-TATGGTAATTGTGTGCCAGCMGCCGCGGTAA-3') and reverse (5'-AGTCAGTCAGCCGGACTACHVGGGTWTCTAAT-3') primers which were previously ligated with unique index combinations (Integrated DNA Technologies, USA): A501-A508/A707, A708 and A709 were used for sequencing. Primers for PCR were reconstituted to $100 \mu \mathrm{M}$ prior to use. PCR was performed in 96 well plates containing $17 \mu \mathrm{l}$ of Accuprime Pfx Supermix (Invitrogen, UK), $1 \mu$ l target DNA, $2 \mu$ l of each primer set. $1 \mu \mathrm{l}$ of PCR grade water was used as a negative control in place of target DNA. PCR conditions consisted of a hot start of $95^{\circ} \mathrm{C}$ for $2 \mathrm{~min}$, followed by $95^{\circ} \mathrm{C}$ for $20 \mathrm{~s}, 55^{\circ} \mathrm{C}$ for $15 \mathrm{~s}$ and $72^{\circ} \mathrm{C}$ for $5 \mathrm{~min}$ ( 30 cycles) with a final elongation of $72{ }^{\circ} \mathrm{C}$ for $10 \mathrm{~min}$. PCR products were visualised on a $1 \%(\mathrm{w} / \mathrm{v})$ agarose gel (Roche Diagnostics, Ireland). PCR products were cleaned and normalised using the SequalPrep Normalization Plate kit (Invitrogen, UK) following manufacturer's instructions. Samples were quantified using a Qubit ${ }^{\mathrm{TM}} 3.0$ Fluorometer (ThermoFisher, UK) and quality checked using a Nanodrop ND-1000 Spectrophotometer (ThermoFisher, UK). Sequencing was carried out by the Centre for Genomic Research, University of Liverpool using an Illumina MiSeq platform. Raw sequences generated were processed using the Mothur software (v.1.34) (Schloss et al., 2009). Illumina adapter sequences were trimmed by cutadapt ver.2.1.1 using option $-\mathrm{O} 3$. Quality filtering using Sickle ver.1.2 further trimmed the data with a quality score of $\geq 20$, followed by removal of reads $<10 \mathrm{bp}$ after trimming. Each read was then trimmed to a maximum of $275 \mathrm{bp}$ and ambiguous bases were removed. Sequences which contained homopolymer runs $>8$ bases were discarded. After trimming, identical sequences were grouped into 'unique' sequences. Chimeric sequences were identified using the UCHIME algorithm within Mothur and were removed. From 2,395,612 contigs, 1,789,505 sequences were constructed and 419,890 unique sequences established. The number of chimeric sequences removed equated to 122,937. 195,731 sequences were then assigned to operational taxonomic units (OTUs) using the 'cluster' command and the average neighbour algorithm. All subsequent OTU-based analyses were performed using a cut-off of 0.03 . Taxonomy was assigned to the aligned sequences by comparing processed data to the silva databases for bacteria (arb-silva.de/silva-license-information). At the grazed site the average number of sequences per sample equated to $27,020 \pm 3465$ standard errors of the mean. For the cut and removed site, the average number of sequences per sample equated to $45,855 \pm 24,638$ standard errors of the mean. To account for differences in the number of sequencing reads between samples, samples were normalised to the biological sample containing the lowest number of reads prior to analysis. Rarefaction curves detailing the depth of sampling intensity showed that for all treatments curves were well saturated (SI Fig. 3). The final bacterial dataset was then generated based on the relative abundances of bacterial genera. The average relative abundance within each biological replicate was calculated according to the rules outlined by Dunbar et al. (2001) i.e. a genus/genus-type had to be present in at least 2 technical replicates (there were 3 technical replicates run for each biological replicate) to be considered.

The relative abundance was first averaged across the technical replicates and this data was used to calculate relative abundance in each biological replicate. Bacterial genera/genus-type with relative 
Table 1

Soil physicochemical parameters for soil at the grazed (G) and cut and removed (C) sites receiving long-term additions of 0 (P0), 15 (P15) or 30 (P30) $\mathrm{kg} \mathrm{ha}^{-1} \mathrm{yr}^{-1} \mathrm{of}$ inorganic phosphorus. Significant differences across rows are denoted by different letters $(\mathrm{p}<0.05)$. Lower case letters indicate differences across the grazed site. Capital letters indicate differences across the cut and removed site $(\mathrm{p}<0.05)$. Standard errors of the mean are shown in parentheses.

\begin{tabular}{|c|c|c|c|c|c|c|}
\hline & \multicolumn{6}{|c|}{ Pi fertilisation rate $\left(\mathrm{kg} \mathrm{ha}^{-1} \mathrm{yr}^{-1}\right)$} \\
\hline & \multicolumn{3}{|l|}{ Grazed site } & \multicolumn{3}{|c|}{ Cut and removed site } \\
\hline & G-P0 & G-P15 & G-P30 & C-P0 & C-P15 & C-P30 \\
\hline Sand (\%) & $51(2)^{\mathrm{a}}$ & $44(5)^{\mathrm{a}}$ & $53(2)^{\mathrm{a}}$ & $47(1)^{\mathrm{A}}$ & $45(1)^{\mathrm{A}}$ & $46(1)^{\mathrm{A}}$ \\
\hline Silt (\%) & $31(1)^{\mathrm{a}}$ & $32(2)^{\mathrm{a}}$ & $29(2)^{\mathrm{a}}$ & $32(1)^{\mathrm{A}}$ & $32(3)^{\mathrm{A}}$ & $30(2)^{\mathrm{A}}$ \\
\hline Clay (\%) & $18(3)^{\mathrm{b}}$ & $17(1)^{\mathrm{b}}$ & $18(1)^{\mathrm{b}}$ & $21(1)^{\mathrm{A}}$ & $23(2)^{\mathrm{A}}$ & $24(2)^{\mathrm{A}}$ \\
\hline $\mathrm{pH}$ & $5.39(0.03)^{\mathrm{a}}$ & $5.77(0.07)^{\mathrm{a}}$ & $5.63(0.02)^{\mathrm{a}}$ & $5.64(0.21)^{\mathrm{A}}$ & $5.91(0.11)^{\mathrm{A}}$ & $5.86(0.14)^{\mathrm{A}}$ \\
\hline Water holding capacity (\%) & $53.00(1.00)^{\mathrm{a}}$ & $51.00(1.00)^{\mathrm{a}}$ & $51.00(1.00)^{\mathrm{a}}$ & $56.00(1.0)^{\mathrm{A}}$ & $53.00(2.00)^{\mathrm{A}}$ & $56.00(1.00)^{\mathrm{A}}$ \\
\hline Total C ( $\mathrm{g} \mathrm{kg}^{-1} \mathrm{DW}$ soil) & $43.80(4.40)^{\mathrm{a}}$ & $45.40(17.10)^{\mathrm{a}}$ & $46.10(4.80)^{\mathrm{a}}$ & $35.90(2.0)^{\mathrm{A}}$ & $37.90(0.70)^{\mathrm{A}}$ & $33.60(0.50)^{\mathrm{A}}$ \\
\hline DOC (mg kg ${ }^{-1}$ DW soil) & $115.40(7.48)^{\mathrm{a}}$ & $105.41(7.96)^{\mathrm{a}}$ & $113.45(1.64)^{\mathrm{a}}$ & $82.06(5.49)^{\mathrm{A}}$ & $84.06(1.48)^{\mathrm{A}}$ & $80.56(3.41)^{\mathrm{A}}$ \\
\hline Total N ( $\mathrm{g} \mathrm{kg}^{-1}$ DW soil) & $4.07(0.44)^{\mathrm{a}}$ & $4.47(0.10)^{\mathrm{a}}$ & $4.59(0.41)^{\mathrm{a}}$ & $3.48(0.41)^{\mathrm{A}}$ & $3.59(0.13)^{\mathrm{A}}$ & $3.24(0.50)^{\mathrm{A}}$ \\
\hline DON (mg kg ${ }^{-1}$ DW soil) & $55.72(14.11)^{\mathrm{a}}$ & $44.71(5.11)^{\mathrm{a}}$ & $48.26(9.39)^{\mathrm{a}}$ & $45.88(5.311)^{\mathrm{A}}$ & $47.38(6.71)^{\mathrm{A}}$ & $31.79(1.36)^{\mathrm{A}}$ \\
\hline $\mathrm{NH}_{4}^{+}-\mathrm{N}\left(\mathrm{mg} \mathrm{kg}^{-1} \mathrm{DW}\right.$ soil) & $18.17(8.58)^{\mathrm{a}}$ & $9.47(0.76)^{\mathrm{a}}$ & $12.59(3.23)^{\mathrm{a}}$ & $11.82(2.08)^{\mathrm{A}}$ & $13.12(1.78)^{\mathrm{A}}$ & $11.29(1.24)^{\mathrm{A}}$ \\
\hline $\mathrm{NO}_{2} / \mathrm{NO}_{3}{ }^{-}-\mathrm{N}\left(\mathrm{mg} \mathrm{kg}^{-1} \mathrm{DW}\right.$ soil) & $20.20\left(2.88^{\mathrm{a}}\right.$ & $16.11(3.53)^{\mathrm{a}}$ & $24.59(9.55)^{\mathrm{a}}$ & $9.67(2.57)^{\mathrm{A}}$ & $6.15(0.46)^{\mathrm{A}}$ & $6.86(1.12)^{\mathrm{A}}$ \\
\hline Total P (P mg kg-1 DW soil) & $437.50(39.00)^{\mathrm{a}}$ & $739.50(64.50)^{\mathrm{b}}$ & $842.80(20.1)^{b}$ & $563.20(16.9)^{\mathrm{A}}$ & $608.9(13.5)^{\mathrm{A}}$ & $639.8(29.30)^{\mathrm{A}}$ \\
\hline Pi (P mg kg ${ }^{-1}$ DW soil) & $3.13(0.24)^{\mathrm{a}}$ & $8.88(1.06)^{\mathrm{ab}}$ & $20.83(2.11)^{\mathrm{b}}$ & $3.08(0.14)^{\mathrm{A}}$ & $2.67(0.14)^{\mathrm{A}}$ & $4.32(0.34)^{\mathrm{B}}$ \\
\hline
\end{tabular}

abundances contributing to $>0.1 \%$ of the total abundance were included in the dataset. Sequence files associated with each sample have been submitted to the European Nucleotide Archive (http://www.ebi. ac.uk/ena), under accession number PRJEB21592.

\subsection{Quantification of bacterial phoD gene}

Real-time PCR (qPCR) was used to quantify copy numbers of the bacterial phoD gene from a standard curve constructed using plasmid from Pseudomonas aeruginosa PA0 (Fraser et al., 2015), using primer set ALPS-F730 (5'-CAGTGGGACGACCACGA GGT-3') and ALPS-R1101 ( 5'-GAGGCCGATCGGCATGTCG-3') (Sigma, UK) (Sakurai et al., 2008). After running a serial dilution on a sub-set of samples to test for inhibition, the phoD assay was performed (Fraser et al., 2015). Each sample was run in triplicate, alongside standards and negative controls on a ViiA7 qPCR instrument (Life Technologies, Ireland), in MicroAmp ${ }^{\circledR}$ optical 96-well reaction plates. Each reaction contained $6.25 \mu \mathrm{l}$ of $2 \mathrm{X}$ KAPA SYBR ${ }^{\circledast}$ FAST qPCR master mix, $0.25 \mu$ ROX $^{\text {TM }}$ low passive reference dye (Anachem, Bedfordshire, UK), with 0.2 pmoles each primer and 2 ng of DNA using software ViiA RUO Ver 1.2.4 Applied Biosystems software (Life Technologies, Ireland) (Storey et al., 2014). The efficiency of the reaction, determined from the standard curve equated to $84 \%\left(R^{2}=0.997\right)$. The melt curve data confirmed no non-specific amplification and no amplification in the negative controls (data not shown).

\subsection{Statistical analyses}

All univariate data was analysed using Minitab v15 (Minitab Ltd). Residuals of the data were assessed for normal distribution using the Anderson-Darling normality test and Levene's test for homogeneity of variances as assumptions to be satisfied before performing parametric tests. One-way ANOVAs were performed to test for an effect of Pi fertilisation rate across each site separately on soil physicochemical and microbial biomass data, bacterial richness scores and changes in relative abundance for the top 24 most abundant bacterial genera, bacterial phoD copy numbers and acid phosphomonoesterase activity.

Multivariate statistics were used to analyse bacterial community structure using the computer programme PRIMER-E version 6.1.9 with the PERMANOVA add-on version 1.0.1. The raw relative abundance data were transformed to the 4th root to down-weigh highly abundant genera whilst recognising those at lower relative abundance (Clarke and Warwick, 2001). The similarity in community structure was determined by calculating Bray-Curtis coefficients between samples which generated a resemblance matrix for comparisons between complex multivariate biological samples to be made (Clarke et al., 2006). Bacterial communities were classified by site (grazed: G or cut: $\mathrm{C}$ ) and further distinguished by Pi fertilisation rate (G-P0, G-P15, G-P30, C-P0, C-P15, C-P30). The bacterial dataset was tested for homogeneity of variances at the lowest level of factor combinations using the PermDisp function in PRIMER-E prior to further analysis.

The bacterial community structure for each Pi fertilisation treatment at both sites was visualised using Non-metric Multidimensional Scaling (NMDS). Differences between community structures exposed to different Pi fertilisation rates were tested by applying statistical permutation-based multivariate analysis of variance tests (PERMANOVA, Anderson, 2001), on the Bray-Curtis resemblance matrix and subsequent pair-wise comparisons (Anderson et al., 2008). For the PERMANOVA test 9999 permutations of the data were performed. Correlations between measured soil parameters were conducted to remove covariates $\left(\mathrm{R}^{2}>0.7\right)$ (SI Table 1$)$. This left 11 soil parameters: $\mathrm{pH}$, moisture content (MC), soil C:P, soil C:N, DOC, $\mathrm{Pi}, \mathrm{NH}_{4}{ }^{+}$, microbial biomass $\mathrm{C}: \mathrm{N}, \mathrm{N}: \mathrm{P}$ and $\mathrm{C}: \mathrm{P}$. BIO-ENV tests were performed to select parameters explaining a significant proportion of variation within the bacterial dataset (Clarke and Ainsworth, 1993; Anderson et al., 2008; Wakelin et al., 2012).

\section{Results}

\subsection{Soil physicochemical properties}

Soil physicochemical properties are shown in Table 1 . Soil pH ranged from 5.39 to 5.77 at the grazed site and from 5.64 to 5.91 at the cut site. Clay content $(\mathrm{F}=13.55, \mathrm{p}=0.016)$, soil $\mathrm{pH}(\mathrm{F}=7.84$, $\mathrm{p}=0.019)$ and water holding capacity $(\mathrm{F}=13.72, \mathrm{p}=0.014)$ were significantly higher at the cut site compared to the grazed site. Under grazing, total soil P and Pi increased significantly with Pi fertilisation, with Pi concentrations increasing from $3.13 \mathrm{mg} \mathrm{kg}^{-1}$ DW soil in unfertilised (G-P0) plots to $20.83 \mathrm{mg} \mathrm{kg}^{-1} \mathrm{DW}$ soil in the G-P30 soil $(F=7.56, p=0.042)$. Total $P$ significantly increased $(F=12.46$, $\mathrm{p}=0.019$ ) in both fertilised plots (G-P15 and G-P30) compared to unfertilised (G-P0) soil (Table 1). Total soil $\mathrm{C}$ and $\mathrm{N}$ were unresponsive to long-term Pi fertilisation rates, along with DOC, DON and inorganic $\mathrm{N}\left(\mathrm{NO}_{3}{ }^{-} / \mathrm{NH}_{4}{ }^{+}\right)$(Table 1$)$. Long-term differences in Pi fertilisation at the cut and removed site resulted in a significantly higher concentration of $\mathrm{Pi}$ in $\mathrm{C}-\mathrm{P} 30$ soil at $4.32 \mathrm{mg} \mathrm{kg}^{-1} \mathrm{DW}$ soil compared to the unfertilised plot (C-P0) at $3.08 \mathrm{mg} \mathrm{kg}^{-1}$ DW soil and C-P15 soil at $2.67 \mathrm{mg} \mathrm{kg}^{-1}$ DW soil (Table 1). No other soil physicochemical 

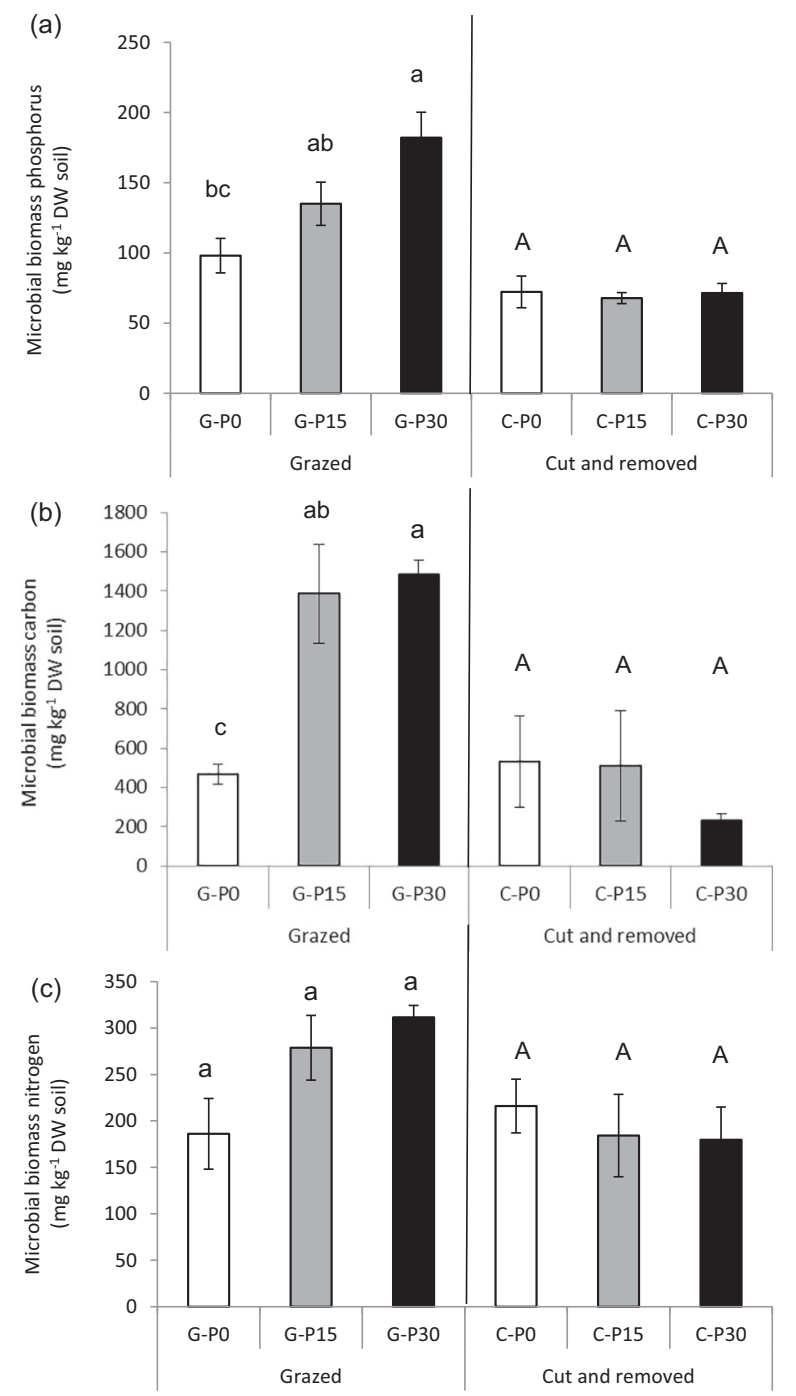

Fig. 1. Mean $(n=3)$ microbial biomass (a) phosphorous, (b) carbon and (c) nitrogen measured in plots receiving long-term inorganic phosphorus fertilisation at 0 (P0) (white bars), 15 (P15) (grey bars) or 30 (P30) (black bars) kg $\mathrm{ha}^{-1} \mathrm{yr}^{-1}$ across the grazed and cut and removed grassland sites. Error bars represent standard errors of the mean. Lower case letters indicate differences across the grazed site. Capital letters indicate differences across the cut and removed site $(\mathrm{p}<0.05)$.

parameter significantly differed across the cut and removed site (Table 1).

\subsection{Soil microbial biomass $C, N$ and $P$}

Under grazing, soil microbial biomass $\mathrm{P}$ and $\mathrm{C}$ increased with $\mathrm{Pi}$ fertilisation rate, and although a similar trend was observed for $\mathrm{N}$, this was not significant (Fig. 1). Microbial biomass P increased significantly with Pi fertilisation rate from $98.05 \mathrm{mg} \mathrm{kg}^{-1} \mathrm{DW}$ soil in unfertilised (G$\mathrm{P0}$ ) soil to $182.10 \mathrm{mg} \mathrm{kg}^{-1} \mathrm{DW}$ soil in G-P30 fertilised soil ( $\mathrm{F}=7.43$, $\mathrm{p}=0.024$ ) (Fig. 1a), mirroring the response of soil Pi (Table 1). Microbial biomass $\mathrm{C}$ (Fig. 1b) mirrored the response of total soil $\mathrm{P}$ (Table 1), increasing significantly from $465.2 \mathrm{mg} \mathrm{kg}^{-1}$ DW soil in unfertilised (G-P0) soil to $1386.5 \mathrm{mg} \mathrm{kg}^{-1}$ DW soil in G-P15 and $1484.6 \mathrm{mg} \mathrm{kg}^{-1} \mathrm{DW}$ soil in G-P30 fertilised soil ( $\left.\mathrm{F}=13.17, \mathrm{p}=0.006\right)$, but not significantly between G-P15 and G-P30 treatments (Fig. 1b). At the cut and removed site, despite a significant difference in soil $\mathrm{Pi}$ concentrations between $\mathrm{C}-\mathrm{P} 0$ and $\mathrm{C}-\mathrm{P} 30$ (Table 1), microbial biomass $\mathrm{C}, \mathrm{P}$ and $\mathrm{N}$ remained constant across the three Pi treatments (Fig. 1).

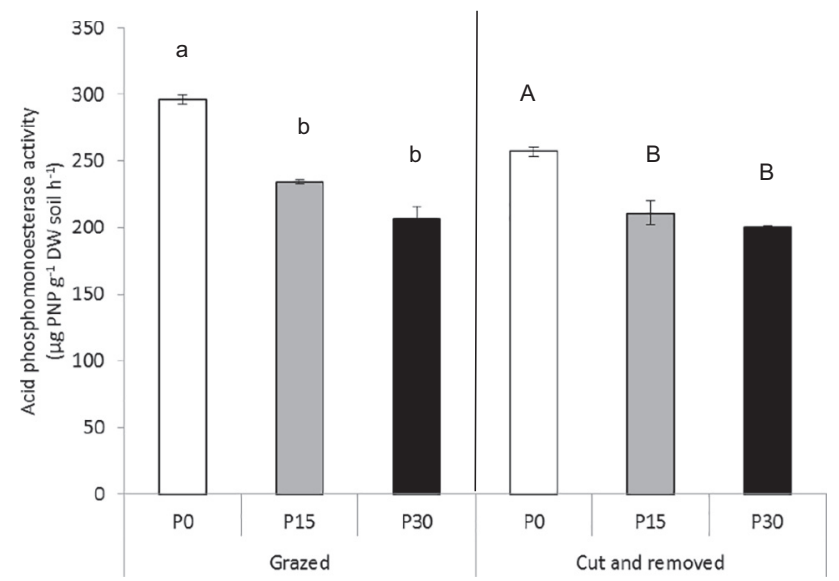

Fig. 2. Mean $(n=3)$ acid phosphomonoesterase activity measured soil from triplicate plots receiving long-term inorganic phosphorus fertilisation at 0 (P0), 15 (P15) or 30 (P30) $\mathrm{kg} \mathrm{ha}^{-1} \mathrm{yr}^{-1}$ across the grazed and cut and removed grassland sites. Error bars represent standard errors of the mean. Lower case letters indicate differences across the grazed site. Capital letters indicate differences across the cut and removed site $(\mathrm{p}<0.05)$.

\subsection{Acid phosphomonoesterase activity}

At the grazed site, phosphomonoesterase activity was significantly $(\mathrm{F}=6.44, \mathrm{p}=0.032)$ higher in unfertilised (G-P0) soil compared to fertilised soil (G-P15 and G-P30 (Fig. 2). A similar trend was observed at the cut and removed site, with activity significantly lower in the C-P30 soil $\left(199.99 \mu \mathrm{g}\right.$ PNP $\mathrm{g}^{-1}$ DW soil $\left.\mathrm{h}^{-1}\right)$ compared to C-P15 or unfertilised C-P0 soils (210.48 and $257.09 \mu \mathrm{g} \mathrm{PNP} \mathrm{g}^{-1}$ DW soil h${ }^{-1}$ ) (Fig. 2).

\subsection{Bacterial richness and community structure in soil exposed to long-term differences in Pi fertilisation rates}

Across both the grazed and cut grassland sites, long-term differences in the Pi fertilisation rates did not result in significant differences in the richness of the bacterial communities (Table 2). However, the NMDS plot suggested differences in bacterial community structures at the grazed site exposed to different long-term Pi fertilisation, whereas no clear clustering appeared evident at the cut site (Fig. 3).

PERMANOVA analysis confirmed bacterial community structure differed significantly $(\mathrm{p}<0.05)$ in soil exposed to different Pi fertilisation rates at the grazed site. Pairwise testing confirmed a significant ( $\mathrm{p}<0.001$ ) difference in bacterial community structure between GP30 and unfertilised (G-P0) soil, with a proportion of the variation significantly explained by soil C:N and C:P (Rho $=0.6, \mathrm{p}=0.03$ ).

Across the cut and removed grassland site, no significant differences were detected in bacterial community structure in response to longterm Pi fertilisation. The BIO-ENV test did not identify any soil parameters explaining a significant proportion of the variation within the bacterial dataset at this site.

\subsection{Response of individual bacterial genera to long-term Pi fertilisation across grazed and cut and removed grassland sites}

Amplicon sequencing revealed Acidobacteria to be the most relatively abundant phylum, with $G p 6$ and $G p 16$ both present within the top 3 most abundant genera at both sites (Table 3a and b). Significant differences in the relative abundances of the top 24 most abundant bacterial genera were detected between Pi fertilisation treatments at the grazed site, but not at the cut and removed site (Table 3a and b). Under grazing, the relative abundance of Bradyrhizobium ( $\mathrm{F}=250.24$, $\mathrm{p}=0.001)$ from the $\alpha$-Proteobacteria was significantly higher in 
Table 2

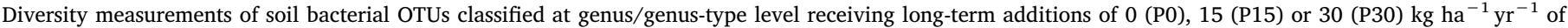

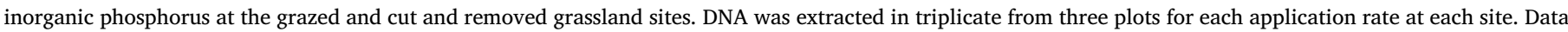

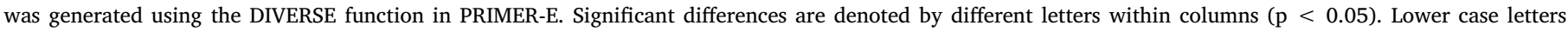
indicate differences across the grazed site, while capital letters indicate differences across the cut and removed site.

\begin{tabular}{|c|c|c|c|c|}
\hline & $\begin{array}{l}\text { Pi fertilisation } \\
\left(\mathrm{kg} \mathrm{ha}^{-1} \mathrm{yr}^{-1}\right)\end{array}$ & $\begin{array}{l}\text { Total genera } \\
(S)\end{array}$ & $\begin{array}{l}\text { Richness } \\
(d)\end{array}$ & $\begin{array}{l}\text { Shannon diversity } \\
\left(H^{\prime} \log ^{e}\right)\end{array}$ \\
\hline \multirow[t]{3}{*}{ Grazed site } & P0 & $201(26)^{a}$ & $44.12(4.75)^{a}$ & $5.14(0.13)^{a}$ \\
\hline & P15 & $190(13)^{a}$ & $42.06(2.67)^{a}$ & $5.09(0.06)^{a}$ \\
\hline & P30 & $166(15)^{a}$ & $37.81(2.90)^{a}$ & $4.94(0.09)^{a}$ \\
\hline \multirow[t]{3}{*}{ Cut and removed site } & P0 & $154(12)^{A}$ & $35.68(2.41)^{A}$ & $4.87(0.08)^{A}$ \\
\hline & P15 & $150(12)^{A}$ & $34.70(2.31)^{A}$ & $4.84(0.09)^{A}$ \\
\hline & P30 & $223(65)^{A}$ & $48.78(12.30)^{A}$ & $5.15(0.25)^{A}$ \\
\hline
\end{tabular}

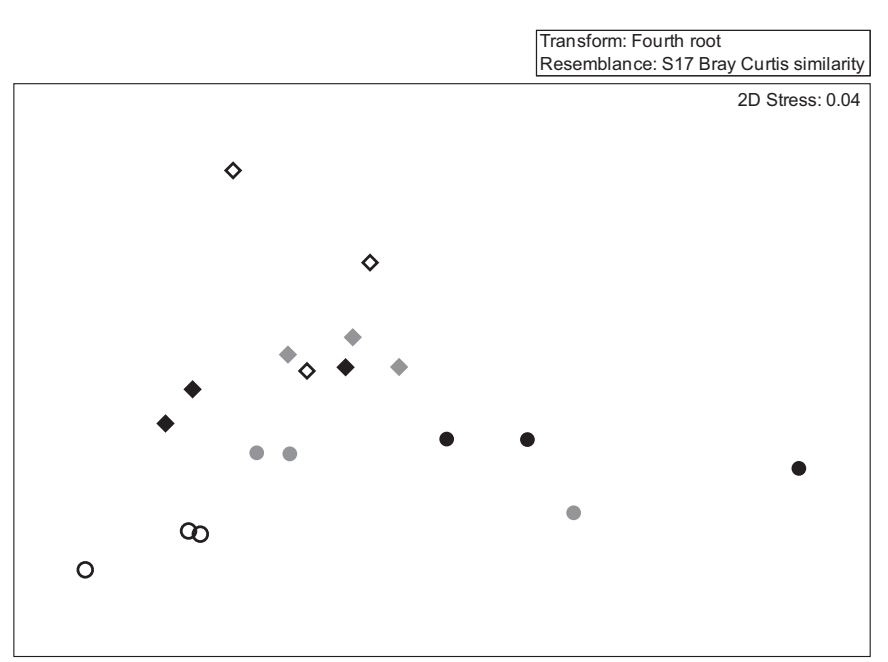

Fig. 3. NMDS plot visually representing bacterial community structures profiled using targeted amplicon sequencing of the bacterial $16 S$ rRNA gene in soil exposed to long-term differences in inorganic phosphorus fertilisation $(n=3)$ at the grazed (G) site: unfertilised (G-P0) (white circles), 15 (G-P15) (grey circles) or 30 (G-P30) (black circles) $\mathrm{kg} \mathrm{ha}^{-1} \mathrm{yr}^{-1}$ and at the cut and removed (C) site: unfertilised (C-P0) (white diamonds), 15 (C-P15) (grey diamonds) or 30 (C-P30) (black diamonds) $\mathrm{kg} \mathrm{ha}^{-1} \mathrm{yr}^{-1}$.

unfertilised (G-P0) soil compared to G-P15 and G-P30 soil. An unclassified genus-type group belonging to Actinobacteria ( $\mathrm{F}=5.73$, $\mathrm{p}=0.041$ ) along with another unclassified genus-type group this time belonging to Acidimicrobiales ( $\mathrm{F}=8.74, \mathrm{p}=0.017$ ) significantly decreased between unfertilised and P30 plots only. In contrast, the relative abundance of bacterial classes belonging to the phylum Acidobacteria showed positive responses to Pi fertilisation: $G p 6$ ( $F=14.84$, $\mathrm{p}=0.005$ ) were relatively more abundant in fertilised (G-P15 and GP30) compared to unfertilised (G-P0) soil, while Gp16 (F = 10.51, $\mathrm{p}=0.011$ ) responded positively to higher $\mathrm{Pi}$ fertilisation (G-P30) compared to unfertilised (G-P0) soil and G-P15 soil (Table 3a).

\subsection{Copy numbers of the bacterial phosphorus mineralising gene phoD}

Under grazing, average copy numbers of the phoD gene increased significantly $\left(\mathrm{F}=6.03, \mathrm{p}=0.037\right.$ ) from $5.1 \times 10^{3} \mathrm{~g}^{-1} \mathrm{DW}$ soil in unfertilised (G-P0) plots to $4.0 \times 10^{4} \mathrm{~g}^{-1}$ DW soil in G-P15 and $4.2 \times 10^{4} \mathrm{~g}^{-1} \mathrm{DW}$ soil in G-P30 treatments, but did not differ significantly between G-P15 and G-P30 plots (Fig. 4).

At the cut and removed site, copy numbers were significantly $(\mathrm{F}=49.91, \mathrm{p}=0.001)$ higher in $\mathrm{C}-\mathrm{P} 30$ plots at $4.7 \times 10^{4} \mathrm{~g}^{-1} \mathrm{DW}$ soil compared to unfertilised (C-P0) at $2.4 \times 10^{4} \mathrm{~g}^{-1}$ DW soil and C-P15 plots at $1.3 \times 10^{4} \mathrm{~g}^{-1} \mathrm{DW}$ soil (Fig. 4).

\section{Discussion}

As expected, the long-term addition of calcium superphosphate increased soil Pi concentrations at both sites (Griffiths et al., 2012; Massey, 2012). The extent of the effect however, differed. Concentrations of Pi, although significantly higher in $\mathrm{C}-\mathrm{P} 30$ plots at the cut and removed site, were markedly lower than corresponding plots at the grazed site. The insensitivity of soil microbial biomass at the cut and removed site is likely a consequence of the lower availability of labile nutrients (i.e. $\mathrm{NO}_{2} / \mathrm{NO}_{3}{ }^{-}$, DOC and Pi) generally observed at this site compared to the grazed. Reasons for the differences between sites however cannot be attributed solely to the difference in management as they are confounded by differences in soil properties, specifically a higher soil pH and clay content at the cut site. Clay is particularly important as it can increase the capacity of phosphate ions to bind to soil particles, reducing Pi availability and can also stabilise microbial biomass (Müller and Höper, 2004). Luckily, within each site, confounding soil factors were not an issue allowing the effect of Pi fertilisation rates on key soil parameters within each site to be assessed.

The effect of long-term differences in Pi fertilisation rate can contribute to differences in vegetation composition (Cruz et al., 2009). Previous work at both sites supports this. At the grazed site, unfertilised (G-P0) plots were dominated by poorer grasses: Common Bent (Agrostis capillaris) and Yorkshire fog (Holcus lanatas), as opposed to perennial ryegrass (Lolium perenne), cocksfoot (Dactylis glomerata), meadow grasses (Poa spp.) and white clover (Trifolium repens) (King-Salter, 2008; Tunney et al., 2010). At the cut and removed site, unfertilised (C-P0) plots were dominated by Bentgrass (Agrostis genus) whereas perennial ryegrass (Lolium perenne) dominated the fertilised (C-P15 and C-P30) plots (Massey et al., 2015). Whilst we cannot untangle the influences of vegetation composition on the soil environment, here we consider it a direct result of the long-term Pi treatments.

\subsection{Bacterial community responses across a Pi fertilisation gradient in grazed and cut and removed grassland soils}

The effects of land-use on soil microbiota have been studied across a range of soil environments including bare fallow, bog, forest and arable (Jangid et al., 2008; Keith et al., 2012; Shange et al., 2012; Neal et al., 2017), but focus has mainly been on differences between extremes and location, rather than agricultural land-use (Keith et al., 2012; Tardy et al., 2015). Studies that have included fertilisation generally compare inorganic vs. organic fertilisers, or combined $\mathrm{N}$ and $\mathrm{P}$ fertilisation vs. unfertilised controls (Lemanski and Scheu, 2015). The current study demonstrates that along a long-term Pi fertilisation gradient, distinctions in bacterial community structures typically occur between unfertilised and Pi fertilised soil, but also only when vegetation is grazed rather than cut and removed.

Despite the changes in bacterial community structure at the grazed site, no change in richness was detected at either site. Microbial richness responses to land-use have been varied (Keith et al., 2012; Tardy 
Table 3

Top 24 bacterial genera/genus-type based on mean relative abundances in a) plots at the grazed (G) site exposed to Pi fertilisation rates (G-0, G-15 and G-

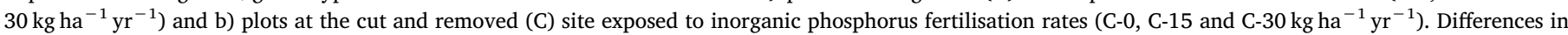
letters within rows indicate significant differences in individual genera $(\mathrm{p}<0.05)$. Bacterial genera/genus-type exhibiting significant differences in relative abundance are highlighted in bold. Standard errors of the mean are shown in parentheses.

\begin{tabular}{|c|c|c|c|c|c|}
\hline \multirow[t]{2}{*}{ Genus/genus-type group } & \multirow[t]{2}{*}{ Phylum } & \multicolumn{3}{|c|}{ Relative abundance (\%) } & \multirow{2}{*}{$\begin{array}{l}\text { Mean relative abundance } \\
(\%)\end{array}$} \\
\hline & & G-P0 & G-P15 & G-P30 & \\
\hline \multicolumn{6}{|l|}{ a) Grazed site } \\
\hline Gp6 & Acidobacteria & $7.84(1.54)^{a}$ & $14.91(1.47)^{b}$ & $20.89(0.37)^{b}$ & 14.55 \\
\hline Spartobacteria_genera_incertae_sedis & Verrucomicrobia & $8.45(4.30)^{a}$ & $14.05(1.46)^{a}$ & $16.90(2.19)^{a}$ & 13.14 \\
\hline Gp16 & Acidobacteria & $7.10(1.18)^{a}$ & $12.13(0.49)^{a b}$ & $15.74(0.60)^{b}$ & 11.66 \\
\hline Prevotella & Bacteroidetes & $0.06(0.04)^{a}$ & $3.69(3.64)^{a}$ & $12.07(9.68)^{a}$ & 5.28 \\
\hline Singulisphaera & Planctomycetes & $3.18(1.66)^{a}$ & $5.03(0.83)^{a}$ & $3.54(1.44)^{a}$ & 3.92 \\
\hline unclassified_Rhizobiales & Proteobacteria & $3.88(1.91)^{a}$ & $4.05(0.82)^{a}$ & $2.45(0.77)^{a}$ & 3.46 \\
\hline unclassified_Bacillaceae_1 & Firmicutes & $3.39(1.71)^{a}$ & $3.47(0.59)^{a}$ & $2.55(0.74)^{a}$ & 3.14 \\
\hline unclassified_Actinobacteria & Actinobacteria & $3.11(1.53)^{a}$ & $3.50(0.78)^{a b}$ & $2.37(0.69)^{b}$ & 3.00 \\
\hline unclassified_Planctomycetaceae & Planctomycetes & $2.06(1.12)^{a}$ & $2.95(0.52)^{a}$ & $2.32(1.01)^{a}$ & 2.44 \\
\hline unclassified_Bacillales & Firmicutes & $2.29(1.14)^{a}$ & $2.69(0.29)^{a}$ & $1.56(0.48)^{a}$ & 2.18 \\
\hline Bradyrhizobium & Proteobacteria & $3.63(0.10)^{a}$ & $0.67(0.16)^{b}$ & $0.30(0.08)^{b}$ & 2.09 \\
\hline unclassified_Veillonellaceae & Actinobacteria & $0.09(0.05)^{a}$ & $1.86(1.80)^{a}$ & $3.33(2.36)^{a}$ & 1.76 \\
\hline unclassified_Prevotellaceae & Firmicutes & $0.04(0.03)^{a}$ & $2.45(2.49)^{a}$ & $2.48(2.13)^{a}$ & 1.66 \\
\hline unclassified_Acidimicrobiales & Bacteroidetes & $2.34(0.07)^{a}$ & $1.66(0.34)^{a b}$ & $0.88(0.25)^{b}$ & 1.63 \\
\hline Gp5 & Acidobacteria & $3.20(3.09)^{a}$ & $0.08(0.02)^{a}$ & $0.03(0.01)^{a}$ & 1.10 \\
\hline Sporosarcina & Firmicutes & $1.11(0.59)^{a}$ & $1.20(0.17)^{a}$ & $0.97(0.33)^{a}$ & 1.09 \\
\hline Acholeplasma & Tenericutes & $2.94(1.27)^{a}$ & $0.00(0.00)^{a}$ & $0.00(0.00)^{a}$ & 0.98 \\
\hline$G p 7$ & Acidobacteria & $1.06(0.53)^{a}$ & $1.03(0.20)^{a}$ & $0.63(0.21)^{a}$ & 0.91 \\
\hline unclassified_Lachnospiraceae & Firmicutes & $0.08(0.02)^{a}$ & $0.74(0.67)^{a}$ & $1.90(1.41)^{a}$ & 0.91 \\
\hline unclassified_Opitutaceae & Verrucomicrobia & $2.72(2.71)^{a}$ & $0.00(0.00)^{a}$ & $0.00(0.00)^{a}$ & 0.91 \\
\hline 3_genus_incertae_sedis & Verrucomicrobia & $0.99(0.52)^{a}$ & $1.04(0.17)^{a}$ & $0.66(0.16)^{a}$ & 0.90 \\
\hline Gp3 & Acidobacteria & $1.29(0.65)^{a}$ & $0.95(0.21)^{a}$ & $0.25(0.08)^{a}$ & 0.83 \\
\hline Gp15 & Acidobacteria & $2.43(0.21)^{a}$ & $0.00(0.00)^{a}$ & $0.00(0.00)^{a}$ & 0.81 \\
\hline Nitrospira & Nitrospira & $2.20(2.06)^{a}$ & $0.13(0.04)^{a}$ & $0.06(0.02)^{a}$ & 0.80 \\
\hline \multicolumn{6}{|l|}{ b) Cut and removed site } \\
\hline Gp6 & Acidobacteria & $19.22(9.69)^{a}$ & $30.73(4.73)^{a}$ & $11.73(7.77)^{a}$ & 19.80 \\
\hline Gp16 & Acidobacteria & $11.62(5.71)^{a}$ & $19.15(3.08)^{a}$ & $8.19(4.60)^{a}$ & 12.51 \\
\hline Spartobacteria_genera_incertae_sedis & Verrucomicrobia & $7.51(3.78)^{a}$ & $14.51(1.22)^{a}$ & $9.20(4.61)^{a}$ & 10.02 \\
\hline unclassified_Actinobacteria & Actinobacteria & $2.87(1.54)^{a}$ & $3.74(0.75)^{a}$ & $3.13(1.73)^{a}$ & 3.13 \\
\hline unclassified_Rhizobiales & Proteobacteria & $2.24(1.17)^{a}$ & $3.45(0.49)^{a}$ & $3.72(2.22)^{a}$ & 3.02 \\
\hline Gp5 & Acidobacteria & $4.92(4.85)^{a}$ & $0.05(0.03)^{a}$ & $4.16(4.03)^{a}$ & 2.93 \\
\hline Singulisphaera & Planctomycetes & $2.08(1.05)^{a}$ & $4.10(0.55)^{a}$ & $2.68(1.34)^{a}$ & 2.85 \\
\hline unclassified_Planctomycetaceae & Planctomycetes & $2.42(1.30)^{a}$ & $4.04(0.43)^{a}$ & $2.24(1.12)^{a}$ & 2.79 \\
\hline unclassified_Bacillaceae_1 & Firmicutes & $1.79(1.01)^{a}$ & $2.65(0.45)^{a}$ & $2.32(1.40)^{a}$ & 2.17 \\
\hline unclassified_Bacillales & Firmicutes & $1.51(0.92)^{a}$ & $2.87(0.60)^{a}$ & $2.21(1.41)^{a}$ & 2.12 \\
\hline Acholeplasma & Tenericutes & $2.99(1.29)^{a}$ & $0.00(0.00)^{a}$ & $3.34(3.21)^{a}$ & 2.03 \\
\hline unclassified_Opitutaceae & Verrucomicrobia & $2.69(1.64)^{a}$ & $0.01(0.00)^{a}$ & $2.88(2.29)^{a}$ & 1.79 \\
\hline Gp15 & Acidobacteria & $2.56(2.01)^{a}$ & $0.02(0.01)^{a}$ & $2.78(1.85)^{a}$ & 1.72 \\
\hline unclassified_Acidimicrobiales & Actinobacteria & $1.46(0.36)^{a}$ & $1.31(0.24)^{a}$ & $1.98(0.38)^{a}$ & 1.53 \\
\hline Nitrospira & Nitrospira & $1.63(1.50)^{a}$ & $0.13(0.03)^{a}$ & $1.90(1.68)^{a}$ & 1.18 \\
\hline 3_genus_incertae_sedis & Verrucomicrobia & $0.92(0.47)^{a}$ & $1.54(1.54)^{a}$ & $1.05(0.54)^{a}$ & 1.12 \\
\hline Phycisphaera & Planctomycetes & $1.50(1.05)^{a}$ & $0.00(0.00)^{a}$ & $1.66(0.31)^{a}$ & 1.01 \\
\hline Gp17 & Acidobacteria & $1.06(0.55)^{a}$ & $1.57(0.37)^{a}$ & $0.52(0.34)^{a}$ & 1.01 \\
\hline Holophaga & Acidobacteria & $1.34(1.24)^{a}$ & $0.00(0.00)^{a}$ & $1.70(1.24)^{a}$ & 0.98 \\
\hline$G p 7$ & Acidobacteria & $0.73(0.39)^{a}$ & $1.65(0.42)^{a}$ & $0.53(0.36)^{a}$ & 0.93 \\
\hline Gp4 & Acidobacteria & $0.90(0.46)^{a}$ & $1.07(0.06)^{a}$ & $0.58(0.27)^{a}$ & 0.82 \\
\hline Sporosarcina & Firmicutes & $0.56(0.31)^{a}$ & $0.99(0.22)^{a}$ & $0.75(0.48)^{a}$ & 0.74 \\
\hline unclassified_Actinomycetales & Actinobacteria & $0.55(0.28)^{a}$ & $0.94(0.17)^{a}$ & $0.78(0.40)^{a}$ & 0.73 \\
\hline Zavarzinella & Planctomycetes & $0.86(0.53)^{a}$ & $0.40(0.04)^{a}$ & $0.83(0.55)^{a}$ & 0.67 \\
\hline
\end{tabular}

et al., 2015), suggesting it may not be an appropriate indicator of microbial responses to agricultural management.

The top 24 most abundant bacterial genera were similar at the two grassland sites. The overall acidity of the soils and similar long-term Pi fertilisation at both sites may have facilitated the establishment of similar bacterial communities over time (Jangid et al., 2008). The profiles of the soil bacteria are also consistent with other agricultural and grassland studies (Jangid et al., 2008; Nacke et al., 2011; Mander et al., 2012; Tan et al., 2013; Luo et al., 2015) suggesting a core bacterial microbiome. An unclassified genus-type belonging to the order Rhizobiales was among the top 24 most relatively abundant genera at both sites; members of this order have been shown to harbour phoD (Ragot et al., 2016) and other P cycling genes (Bergkemper et al., 2016a). Significant differences in the individual relative abundances were however only detected under grazing: Bradyrhizobium - a common rhizosphere dwelling genus significantly decreased with Pi fertilisation between unfertilised (G-P0) and fertilised (G-P15 and G-P30) grazed soil. Although Bradyrhizobium is typically associated with N-fixation, higher relative abundances have been observed at low soil Pi concentrations and linked to improved plant performance (Tairo and Ndakidemi, 2013; Nyoki and Ndakidemi, 2014), and P mobilisation (Mander et al., 2012; Wakelin et al., 2012). One possible explanation is that $\mathrm{N}$ fixing organisms such as Bradyrhizobium invest $\mathrm{N}$ for production of $\mathrm{N}$ rich phosphatase enzymes (such as involved in $\mathrm{P}$ mineralisation) when soil P concentrations are low (Nasto et al., 2014). An unclassified genus-type belonging to Actinobacteria also responded negatively to $\mathrm{Pi}$ fertilisation, but in G-P30 plots only. The phylum Actinobacteria has been closely linked with P solubilisation in soil (Mander et al., 2012) 


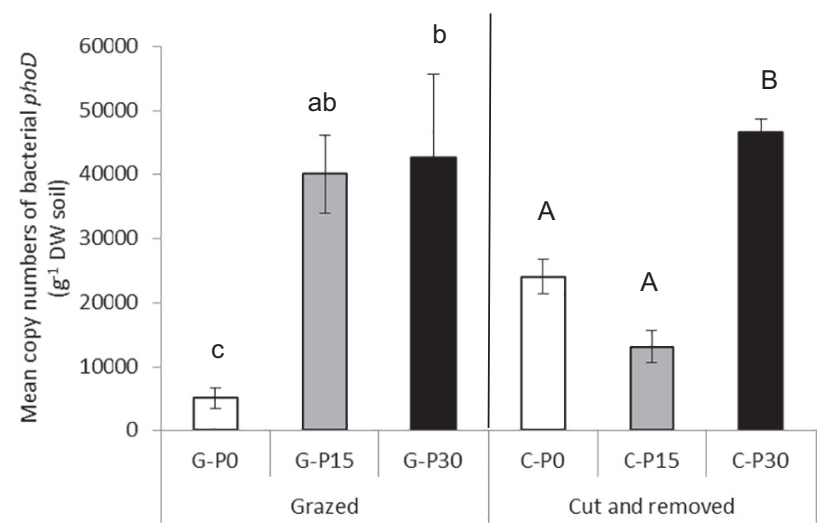

Fig. 4. Mean $(n=3)$ copy numbers of a bacterial alkaline phosphatase gene phoD from triplicate plots receiving long-term inorganic phosphorus fertilisation at 0 (P0), 15 (P15) or 30 (P30) $\mathrm{kg} \mathrm{ha}^{-1} \mathrm{yr}^{-1}$ across the (a) grazed and (b) cut and removed grassland sites. Error bars represent standard errors of the mean. Lower case letters indicate differences across the grazed site. Capital letters indicate differences across the cut and removed site $(\mathrm{p}<0.05)$.

and previously reported to respond negatively to $\mathrm{Pi}$ fertilisation (Wakelin et al., 2012).

Conversely, the relative abundance of genera belonging to the phylum Acidobacteria responded positively to $\mathrm{Pi}$ fertilisation under grazing. Acidobacteria are estimated to comprise $20 \%$ of bacteria within grassland soils (Quaiser et al., 2003), dominated by the genera Gp6 (Naether et al., 2012), Gp4, Gp16 and Gp7 (Will et al., 2010) as observed in this study. Acidobacteria have been suggested to be associated with oligotrophic environments due to their relatively slow growth (Jangid et al., 2008), however continual detection across a range of agricultural soils suggests ecological roles currently not understood (Nunes da Rocha et al., 2013). Previous work at the grazed site used in the current study reported a negative response of the Acidobacteria to Pi fertilisation (Tan et al., 2013). This discrepancy may reflect the different sequencing approaches (Roche 454 pyrosequencing vs. Illumina), and time of year samples were collected.

Soils are dynamic systems which respond to changes in the surrounding environment. Seasonality is a key moderator of substrate availability, microbial activity and can shape community structures (Dumbrell et al., 2011; Sorensen et al., 2013; Slaughter et al., 2015). For example, seasonal effects were previously detected at the cut and removed site on soil $\mathrm{Pi}$, microbial biomass C and PLFA profiles (Massey et al., 2015). It should be noted however that while Pi concentrations changed in the abovementioned study, they remained relatively low. Nonetheless, this highlights the need to undertake longer-term studies sampled across seasons, using standardised techniques (Philippot et al., 2012), with similar levels of discrimination and coverage before we can inform future strategies for sustainable agriculture.

\subsection{Insights into $P$ cycling across a Pi fertilisation gradient in grazed and cut and removed grassland soils}

The capacity for $\mathrm{P}$ mineralisation is a relatively broad function within soil microorganisms (Ragot et al., 2016), with genetic similarity in P mineralising genes observed across agricultural soils (Neal et al., 2017). One of the key enzymes involved in P mineralisation, phosphomonoesterase's activity typically decreases as Pi availability increases (Olander and Vitousek, 2000; Shi et al., 2013; Turner and Wright, 2014) and similar results were observed at both sites in the current study. The decrease in activity in soils with higher Pi concentrations most likely reflects more efficient microbial P uptake systems in P-depleted soil (Bergkemper et al., 2016a).

In contrast, copy numbers of $p h o D$ increased with Pi fertilisation and numbers were relatively similar between sites. The abundance of this gene has been shown to respond in a similar manner to Pi fertilisation in other studies (Keith et al., 2012; Chhabra et al., 2013; Tan et al., 2013; Fraser et al., 2015; Ragot et al., 2016). Although phoD is considered the most abundant monophosphatase gene within soil and marine environments (Luo et al., 2009; Neal et al., 2017) and has been used as a proxy for bacterial P mineralisation (Tan et al., 2013; Fraser et al., 2015; Acuña et al., 2016; Ragot et al., 2016), it only provides partial insight into microbial $\mathrm{P}$ mineralisation. The inclusion of additional P mineralising genes such as phoA and phoX (Ragot et al., 2016) and a phoD primer set offering better coverage (Bergkemper et al., 2016b) might have provided greater overview of this process. A metatranscriptomic or metaproteomic analysis targeting additional microbial P cycling pathways would afford even greater insight.

The different response of a $\mathrm{P}$ cycling enzyme and the abundance of a gene encoding a phosphatase likely reflects the fact that gene abundance is merely a measure of the specific $\mathrm{P}$ cycling potential of the bacterial community, whereas the enzyme represents a direct measure of more general microbial activity and/or the absence of a direct relationship between the enzyme and gene measured. Despite differences in microbial biomass and soil Pi concentrations between the grazed and cut sites, bacterial phoD copy numbers and phosphomonoesterase activity were relatively similar in both sites. This suggests bacterial phoD copy numbers were not solely related to microbial biomass, and that $\mathrm{P}$ mineralisation may be an important mode of Pi mobilisation within reduced input systems. In soils where organic matter inputs are reduced i.e. bare fallow, a dependence on P mineralising exoenzymes has been detected, alongside increased phytate mineralisation (a recalcitrant source of organic P) (Neal et al., 2017). Copy numbers of $\beta$-propeller phytases involved in phytate mineralisation have also been documented to increase in reduced input systems (Neal et al., 2017), and when soil Pi concentrations are low (Jorquera et al., 2013). It would be interesting to explore this further across our two sites.

\section{Conclusions}

At the grazed site, increasing long-term Pi fertilisation rates resulted in increased soil $\mathrm{P}$ concentrations, increased microbial biomass $\mathrm{C}$ and $\mathrm{P}$, significant shifts in bacterial community structures and differences in the relative abundances of some bacterial genera. In contrast at the cut and removed site, microbial biomass (C, N and P) and bacterial community structures did not respond to long-term increases in Pi fertilisation and soil Pi concentrations only increased under the highest fertilisation rate (C-P30). Despite differences in soil P concentrations and microbial biomass between the two sites, the abundance of phoD increased with increasing soil Pi across both sites, while phosphomonoesterase activity decreased. The current study demonstrates the potential impacts intensive cutting and removal of vegetation may impose on Pi fertiliser effectiveness, both in terms of $\mathrm{P}$ accumulation and the bacterial community. The identification of bacterial genera that respond to different rates of Pi fertilisation in grazed soil provides the opportunity to further examine the role of these genera within terrestrial P cycling.

\section{Acknowledgements}

This research was conducted as part of the Earth and Natural Sciences Doctoral Studies Programme, funded under the Programme for Research in Third-Level Institutions and co-funded under the European Regional Development Fund. We are grateful to technical staff at Teagasc Environmental Research Centre. We are also thankful to John Murphy and additional members of Teagasc staff who helped establish and maintain the field trials used in the study. Work at SRUC was funded by the Scottish Government, Rural and Environment, Science and Analytical Services Division. The authors would also like to acknowledge the knowledge provided by Dr. John McGrath (Queen's University Belfast) concerning microbial P cycling, Dr. Jim Grant 
(Teagasc, Ireland) and Dr. Robert Ferguson (University of Essex) for their input on the statistical approach for the data, and Dr. Corinne Whitby (University Essex) for editing advice. The authors do not consider there to be any conflict of interest concerning this research.

\section{Appendix A. Supplementary data}

Supplementary data to this article can be found online at https:// doi.org/10.1016/j.apsoil.2019.02.002.

\section{References}

Abdalla, M., Hastings, A., Chadwick, D.R., Jones, D.L., Evans, C.D., Jones, M.B., Rees, R.M., Smith, P., 2018. Critical review of the impacts of grazing intensity on soil organic carbon storage and other soil quality indicators in extensively managed grasslands. Agric. Ecosyst. Environ. 253, 62-81.

Acuña, J.J., Durán, P., Lagos, L.M., Ogram, A., de la Luz Mora, M., Jorquera, M.A., 2016. Bacterial alkaline phosphomonoesterase in the rhizospheres of plants grown in Chilean extreme environments. Biol. Fertil. Soils 52, 763-773.

Anderson, M., 2001. A new method for non-parametric multivariate analysis of variance. Austral Ecol. 26, 32-46.

Anderson, M.J., Gorley, R.N., Clarke, K.R., 2008. PERMANOVA + for PRIMER: Guide to Software and Statistical Methods. (Plymouth, UK).

Azziz, G., Bajsa, N., Haghjou, T., Taulé, C., Valverde, Á., Igual, J.M., Arias, A., 2012. Abundance, diversity and prospecting of culturable phosphate solubilizing bacteria on soils under crop-pasture rotations in a no-tillage regime in Uruguay. Appl. Soil Ecol. 61, 320-326.

Baird, R.B., 2005. Aggregate organic constituents; total organic carbon (TOC)/method 5310 B high temperature combustion method. In: Eaton, D.A., Classer, L.S., Rice, E.W., Greensburg, A.E. (Eds.), Standard Methods for the Examination of Waters and Waste Water, 21st ed. American Public Health Association, Washington DC.

Bergkemper, F., Kublik, S., Lang, F., Krüger, J., Vestergaard, G., Schloter, M., Schulz, S., 2016b. Novel oligonucleotide primers reveal a high diversity of microbes which drive phosphorous turnover in soil. J. Microbiol. Methods 125, 91-97.

Bergkemper, F., Schöler, A., Engel, M., Lang, F., Krüger, J., Schloter, Schulz, S., 2016a. Phosphorus depletion in forest soils shapes bacterial communities towards phosphorus recycling systems. Environ. Microbiol. 18, 1988-2000.

Brookes, P.C., Powlson, D.S., Jenkinson, D.S., 1982. Measurement of microbial biomass phosphorus in soil. Soil Biol. Biochem. 14, 319-329.

Cabrera, M.L., Beare, M.H., 1993. Alkaline persulfate oxidation for determining total nitrogen in microbial biomass extracts. Soil Sci. Soc. Am. J. 57, 1007-1012. https:// doi.org/10.2136/sssaj1993.03615995005700040021x.

Chen, X., Daniell, T.J., Neilson, R., O'Flaherty, V., Griffiths, B.S., 2014. Microbial and microfaunal communities in phosphorus limited, grazed grassland change composition but maintain homeostatic nutrient stoichiometry. Soil Biol. Biochem. 75, 94-101.

Chhabra, S., Brazil, D., Morrissey, J., Burke, J., O'Gara, F., Dowling, D., 2013. Fertilization management affects the alkaline phosphatase bacterial community in barley rhizosphere soil. Biol. Fertil. Soils 49, 31-39.

Clarke, K.R., Ainsworth, M., 1993. A method of linking multivariate community structure to environmental variables. Mar. Ecol. Prog. Ser. 92, 205-219.

Clarke, K.R., Somerfield, P.J., Chapman, M.G., 2006. On resemblance measures for ecological studies, including taxonomic dissimilarities and a zero-adjusted bray-Curtis coefficient for denuded assemblages. J. Exp. Mar. Biol. Ecol. 330, 55-80.

Clarke, K.R., Warwick, R.M., 2001. Change in Marine Communities: An Approach to Statistical Analysis and Interpretation. Primer-E Ltd, Plymouth, UK.

COM, 2000/60/EC of the European Parliament and of the Council of 23 October, 2000. Establishing a Framework for Community Action in the Field of Water Policy. Commission of the European Communities, Brussels.

COM, 91/676/EEC of the Council of December 12, 1991. Concerning the Protection of Waters Against Pollution Caused by Nitrates From Agricultural Sources European Commission, Brussels.

Cruz, A., Hamel, C., Hanson, K., Selles, F., Zentner, R.P., 2009. Thirty-seven years of soil nitrogen and phosphorus fertility management shapes the structure and function of the soil microbial community in a Brown Chernozem. Plant Soil 315, 173-184.

Culleton, E., 1972. Laboratory analyses in soil survey investigations: theory and techniques. In: An Foras Talúntais National Soil Survey, Johnstown Castle, Wexford, Republic of Ireland.

Culleton, N., Coulter, B., Liebhardt, W.C., 2002. The fate of phosphatic fertiliser applied to grassland. Ir. Geogr. 35, 175-184.

Daly, K., Casey, A., 2006. Environmental aspects of soil phosphorus testing. Ir. J. Agric. Food Res. 44, 261-279.

De Vries, F.T., Jørgensen, H.B., Hedlund, K., Bardgett, R.D., 2015. Disentangling plant and soil microbial controls on carbon and nitrogen loss in grassland mesocosms. J. Ecol. 103, 629-640.

Dotaniya, M.L., Meena, V.D., 2014. Rhizosphere effect on nutrient availability in soil and its uptake by plants: a review. Proc. Natl. Acad. Sci. India Sect. B (Biol. Sci). 85, 1-12.

Dumbrell, A.J., Ashton, P.D., Aziz, N., Feng, G., Nelson, M., Dytham, C., Fitter, A.H., Helgason, T., 2011. Distinct seasonal assemblages of arbuscular mycorrhizal fungi revealed by massively parallel pyrosequencing. New Phytol. 190, 794-804.

Dunbar, J., Ticknor, L.O., Kuske, C.R., 2001. Phylogenetic specificity and reproducibility and new method for analysis of terminal restriction fragment profiles of 16S rRNA genes from bacterial communities. Appl. Environ. Microbiol. 67, 190-197.

EPA, 2007. Method 3051A, Microwave assisted acid digestion of sediments, sludges, soils and oils, 1-30. Available online: http://www.caslab.com/EPA-Methods/PDF/EPAMethod-3051A.pdf, Accessed date: 16 February 2012.

EU, 2014. Good agricultural practice for protection of waters regulations. Statutory Instruments No. 31 of 2014. pp. 1-50. Available online. https://www.agriculture. gov.ie/media/migration/ruralenvironment/environment/nitrates/ SI31 of2014290114.pdf, Accessed date: 13 November 2015.

FAO, 2010. Challenges and opportunities for carbon sequestration in grassland systems: A Technical Report on Grassland Management and Climate Change Mitigation, Integrated Crop Management. 9, 1-67. Available online: http://www.fao.org/ fileadmin/templates/agphome/documents/climate/AGPC_grassland_webversion_19. pdf, Accessed date: 2 November 2016.

FAO, 2015. Soil is a non-renewable resource. Available online: http://www.fao.org/ fileadmin/user_upload/soils2015/docs/EN/IYS_fact_sheets_preservation_en_PRINT. pdf, Accessed date: 4 January 2015.

Fitter, A.H., Graves, J.D., Wolfenden, J., Self, G.K., Brown, T.K., Bogie, D., Mansfield, T.A., 1997. Root production and turnover and carbon budgets of two contrasting grasslands under ambient and elevated atmospheric carbon dioxide concentrations. New Phytol. 137, 47-255.

Fraser, T., Lynch, D.H., Entz, M.H., Dunfield, K.E., 2015. Linking alkaline phosphatase activity with bacterial phoD gene abundance in soil from a long-term management trial. Geoderma 257-258, 115-122.

Gorazda, K., Wzorek, Z., Tarko, B., Nowak, A.K., Kulczycka, J., Henclik, A., 2013. Phosphorus cycle - possibilities for its rebuilding. Acta Biochim. Pol. 60, 725-730.

Griffiths, B.S., Spilles, A., Bonkowski, M., 2012. C:N:P stoichiometry and nutrient limitation of the soil microbial biomass in a grazed grassland site under experimental P limitation or excess. Ecol. Process. 1, 1-11.

Griffiths, R.I., Whiteley, A.S., Anthony, G., Donnell, O., Bailey, M.J., Donnell, A.G.O., 2000. Rapid method for coextraction of DNA and RNA from natural environments for analysis of ribosomal DNA- and rRNA-based microbial community composition. Appl. Environ. Microbiol. 66, 5488-5491.

Hedley, M.J., Stewart, J.W.B., 1982. Method to measure microbial phosphate in soils. Soil Biol. Biochem. 14, 377-385.

Hungate, B.A., Holland, E.A., Jackson, R.B., Chapin, F.S., Mooney, H.A., Field, C.B., 1997. The fate of carbon in grasslands under carbon dioxide enrichment. Nature 388, 576-579.

Isselstein, J., Jeangros, B., Pavlu, V., 2005. Agronomic aspects of biodiversity targeted management of temperate grasslands in Europe - a review. Agron. Res. 3, 139-151.

IUSS Working Group WRB, 2015. World Reference Base for Soil Resources 2014, update 2015 International soil classification system for naming soils and creating legends for soil maps. In: World Soil Resources Reports No. 106. FAO, Rome Available online: http://www.fao.org/3/i3794en/I3794en.pdf, Accessed date: 15 October 2012.

Jangid, K., Williams, M.A., Franzluebbers, A.J., Sanderlin, J.S., Reeves, J.H., Jenkins, M.B., Endale, D.M., Coleman, D.C., Whitman, W.B., 2008. Relative impacts of landuse, management intensity and fertilization upon soil microbial community structure in agricultural systems. Soil Biol. Biochem. 40, 1-11.

Jenkinson, D.S., Brookes, P.C., Powlson, D.S., 2004. Measuring soil microbial biomass. Soil Biol. Biochem. 36, 5-7.

Jenkinson, D.S., Powlson, D.S., 1976. The effects of biocidal treatments on metabolism in soil-I. Fumigation with chloroform. Soil Biol. Biochem. 8, 167-177.

Jorquera, M.A., Martínez, O.A., Marileo, L.G., Acuña, J.J., Saggar, S., Mora, M.L., 2013 Effect of nitrogen and phosphorus fertilization on the composition of rhizobacterial communities of two Chilean Andisol pastures. World J. Microbiol. Biotechnol. 30, 99-107.

Kageyama, H., Tripathi, K., Rai, A., Cha-Um, S., Waditee-Sirisattha, R., Takabe, T., 2011. An alkaline phosphatase/phosphodiesterase, $P h o D$, induced by salt stress and secreted out of the cells of Aphanothece halophytica, a halotolerant cyanobacterium. Appl. Environ. Microbiol. 77, 5178-5183.

Keith, A.M., Boots, B., Hazard, C., Niechoj, R., Arroyo, J., Bending, G.D., Bolger, T., Breen, J., Clipson, N., Doohan, F.M., Griffin, C.T., Schmidt, O., 2012. Cross-taxa congruence, indicators and environmental gradients in soils under agricultural and extensive land management. Eur. J. Soil Biol. 49, 55-62.

King-Salter, G.E., 2008. Response of Arbuscular Mycorrhizal Fungi to Seasonality and Long-term Phosphorus Fertilisation in an Irish Grazed Grassland. PhD Thesis. University College Dublin, Dublin, Ireland.

Kozich, J.J., Westcott, S.L., Baxter, N.T., Highlander, S.K., Schloss, P.D., 2013. Development of a dual-index sequencing strategy and curation pipeline for analyzing amplicon sequence data on the miseq illumina sequencing platform. Appl. Environ. Microbiol. 79, 5112-5120.

Lemanski, K., Scheu, S., 2015. The influence of fertilizer addition, cutting frequency and herbicide application on soil organisms in grassland. Biol. Fertil. Soils 51, 197-205.

Liebisch, F., Keller, F., Huguenin-Elie, O., Frossard, E., Oberson, A., Bünemann, E.K., 2014. Seasonal dynamics and turnover of microbial phosphorus in a permanent grassland. Biol. Fertil. Soils 50, 465-475.

Luo, H., Benner, R., Long, R.A., Hu, J., 2009. Subcellular localization of marine bacterial alkaline phosphatase. PNAS 106, 21219-21223. https://doi.org/10.1073/pnas. 0907586106.

Luo, P., Han, X., Wang, Y., Han, M., Shi, H., Liu, N., Bai, H., 2015. Influence of long-term fertilization on soil microbial biomass, dehydrogenase activity, and bacterial and fungal community structure in a brown soil of northeast China. Ann. Microbiol. 65, 533-542.

Mander, C., Wakelin, S., Young, S., Condron, L., O'Callaghan, M., 2012. Incidence and diversity of phosphate-solubilising bacteria are linked to phosphorus status in grassland soils. Soil Biol. Biochem. 44, 93-101.

Massey, P.A., 2012. Interactions Between Phosphorus Fertilisation and Soil Biota in 
Managed Grassland Systems. PhD Thesis. Cranfield University, UK.

Massey, P.A., Creamer, R.E., Whelan, M.J., Ritz, K., 2015. Insensitivity of soil biological communities to phosphorus fertilization in intensively managed grassland systems. Grass Forage Sci. 71, 139-152.

McCormack, S., 2002. Analysis of agricultural materials: Methods used at Johnstown Castle Research Centre. vol. 2 Johnstown Castle Research Centre, Wexford, Ireland.

McSherry, M.E., Ritchie, M.E., 2013. Effects of grazing on grassland soil carbon: a global review. Glob. Chang. Biol. 19, 1347-1357.

Müller, T., Höper, H., 2004. Soil organic matter turnover as a function of the soil clay content: consequences for model applications. Soil Biol. Biochem. 36, 877-888.

Mulvaney, R.L., 1996. Nitrogen—inorganic forms. In: Sparks, D.L., Page, A.L., Helmke, P.A., Loeppert, R.H., Soltanpour, P.N., Tabatabai, M.A., Johnson, C.T., Sumner, M.E. (Eds.), Methods of Soil Analysis Part 3. SSSA, Madison, pp. 1123-1184.

Murphy, J., Riley, J.P., 1962. A modified single solution method for the determination of phosphate in natural waters. Anal. Chim. Acta 27, 31-36.

Nacke, H., Thürmer, A., Wollherr, A., Will, C., Hodac, L., Herold, N., Schöning, I. Schrumpf, M., Daniel, R., 2011. Pyrosequencing-based assessment of bacterial community structure along different management types in German Forest and Grassland soils. PLoS One 6, 1-12. https://doi.org/10.1371/journal.pone.0017000.

Naether, A., Foesel, B.U., Naegele, V., Wüst, P.K., Weinert, J., Bonkowski, M., Alt, F., Oelmann, Y., Polle, A., Lohaus, G., Gockel, S., Hemp, A., Kalko, E.K.V., Linsenmair, K.E., Pfeiffer, S., Renner, S., Schöning, I., Weisser, W.W., Wells, K., Fischer, M., Overmann, J., Friedrich, M.W., 2012. Environmental factors affect acidobacterial communities below the subgroup level in grassland and forest soils. Appl. Environ. Microbiol. 78, 7398-7406.

Nasto, M.K., Alvarez-Clare, S., Lekberg, Y., Sullivan, B.W., Townsend, A.R., Cleveland, C.C., 2014. Interactions among nitrogen fixation and soil phosphorus acquisition strategies in lowland tropical rain forests. Ecol. Lett. 17, 1282-1289.

Neal, A.L., Rossmann, M., Brearley, C., Akkari, E., Guyomar, C., Clark, I.M., Allen, E., Hirsch, P.R., 2017. Land-use influences phosphatase gene microdiversity in soil. Environ. Microbiol. 19, 2740-2753.

Nitschelm, J.J., Luscher, A., Hartwig, U.A., van Kessel, C., 1997. Using stable isotopes to determine soil carbon input differences under ambient and elevated atmospheric $\mathrm{CO}_{2}$ conditions. Glob. Chang. Biol. 3, 411-416.

Nunes da Rocha, U., Plugge, C.M., George, I., van Elsas, J.D., van Overbeek, L.S., 2013. The rhizosphere selects for particular groups of Acidobacteria and Verrucomicrobia. PLoS One 8. https://doi.org/10.1371/journal.pone.0082443.

Nyoki, D., Ndakidemi, P.A., 2014. Effects of Bradyrhizobium japonicum inoculation and supplementation with phosphorus on macronutrients uptake in cowpea (Vigna unguiculata (L.) Walp). Am. J. Plant Sci. 5, 442-451.

Olander, L.P., Vitousek, P.M., 2000. Regulation of soil phosphatase and chitinase activity by $\mathrm{N}$ and $\mathrm{P}$ availability. Biogeochemistry 49, 175-190.

O'Mara, F.P., 2012. The role of grasslands in food security and climate change. Ann. Bot. $110,1263-1270$.

Osorio, N., Habte, M., 2013. Phosphate desorption from the surface of soil mineral particles by a phosphate-solubilizing fungus. Biol. Fertil. Soils 49, 481-486.

Owen, D., Williams, A.P., Griffith, G.W., Withers, P.J.A., 2015. Use of commercial bioinoculants to increase agricultural production through improved phosphorous acquisition. Appl. Soil Ecol. 86, 41-54.

Parsons, A.J., Thronley, J.H.M., Newton, P.C.D., Rasmussen, S., Rowarth, J.S., 2013. Soil carbon dynamics: the effect of nitrogen input, intake demand and off-take by animals. Sci. Total Environ. 465, 205-215.

Philippot, L., Ritz, K., Pandard, P., Hallin, S., Martin-Laurent, F., 2012. Standardisation of methods in soil microbiology: Progress and challenges. FEMS Microbiol. Ecol. 82, $1-10$.

Poeplau, C., Marstop, H., Thorez, K., Kätterer, T., 2016. Effect of grassland cutting frequency on soil carbon storage - a case study on public lawns in three Swedish cities. Soil 2, 175-184.

Quaiser, A., Ochsenreiter, T., Lanz, C., Schuster, S.C., Treusch, A.H., Eck, J., Schleper, C., 2003. Acidobacteria form a coherent but highly diverse group within the bacterial domain: evidence from environmental genomics. Mol. Microbiol. 50, 563-575.

Ragot, S.A., Kertesz, M.A., Bünemann, E.K., 2016. phoD alkaline phosphatase gene diversity in soil. Appl. Environ. Microbiol. 81, 7281-7289.

Richardson, A.E., Simpson, R.J., 2011. Soil microorganisms mediating phosphorus availability update on microbial phosphorus. Plant Physiol. 156, 989-996.

Rumpel, C., Crème, A., Ngo, P.T., Velásquez, G., Mora, M.L., Chabbi, A., 2015. The impact of grassland management on biogeochemical cycles involving carbon, nitrogen and phosphorus. J. Soil Sci. Plant Nutr. 15, 353-371.

Sakurai, M., Wasaki, J., Tomizawa, Y., Shinano, T., Osaki, M., 2008. Analysis of bacterial communities on alkaline phosphatase genes in soil supplied with organic matter. J.
Soil Sci. Plant Nutr. 54, 62-71.

Schloss, P.D., Westcott, S.L., Ryabin, T., Hall, J.R., Hartmann, M., Hollister, E.B., Lesniewski, R.A., Oakley, B.B., Parks, D.H., Robinson, C.J., Sahl, J.W., Stres, B. Thallinger, G.G., Van Horn, D.J., Weber, C.F., 2009. Introducing mothur: opensource, platform-independent, community-supported software for describing and comparing microbial communities. Appl. Environ. Microbiol. 75, 7537-7541.

Shange, R.S., Ankumah, R.O., Ibekwe, A.M., Zabawa, R., Dowd, S.E., 2012. Distinct soil bacterial communities revealed under a diversely managed agroecosystem. PLoS One 7, e40338. https://doi.org/10.1371/journal.pone.0040338.

Sharma, S.B., Sayyed, R.Z., Trivedi, M.H., Gobi, T.A., 2013. Phosphate solubilizing microbes: sustainable approach for managing phosphorus deficiency in agricultural soils. Springerplus 2, 1-14. https://doi.org/10.1186/2193-1801-2-587.

Shi, Y., Lalande, R., Hamel, C., Ziadi, N., Gagnon, B., Hu, Z., 2013. Seasonal variation of microbial biomass, activity, and community structure in soil under different tillage and phosphorus management practices. Biol. Fertil. Soils 49, 803-818.

Simpson, R.J., Oberson, A., Culvenor, R.A., Ryan, M.H., Veneklaas, E.J., Lambers, H., Lynch, J.P., Ryan, P.R., Delhaize, E., Smith, F.A., Smith, S.E., Harvey, P.R., Richardson, A.E., 2011. Strategies and agronomic interventions to improve the phosphorus-use efficiency of farming systems. Plant Soil 349, 89-120.

Sims, J.T., Sharpley, A.N. (Eds.), 2005. Phosphorus: Agriculture and the environment Agronomy monograph no. 46. American Society of Agronomy, Inc.; Crop Science Society of America, Inc.; Soil Science Society of America, Inc., United States of America.

Slaughter, L.C., Weintraub, M.N., McCulley, R.L., 2015. Seasonal effects stronger than three-year climate manipulation on grassland soil microbial community. Soil Sci. Soc. Am. J. 79.

Sorensen, P.O., Germino, M.J., Feris, K.P., 2013. Microbial community responses to 17 years of altered precipitation are seasonally dependent and coupled to co-varying effects of water content on vegetation and soil C. Soil Biol. Biochem. 64, 155-163.

Storey, S., Ashaari, M.M., McCabe, G., Harty, M., Dempsey, R., Doyle, O., Clipson, N. Doyle, E.M., 2014. Microbial community structure during fluoranthene degradation in the presence of plants. J. Appl. Microbiol. 11, 74-84.

Stutter, M.I., 2015. The composition, leaching, and sorption behaviour of some alternative sources of phosphorus for soils. Ambio 44, 207-216. https://doi.org/10.1007/ s13280-014-0615-7.

Tabatabai, M.A., Bremner, J.M., 1969. Use of p-nitrophenyl phosphate for assay of soil phosphatase activity. Soil Biol. Biochem. 1, 301-307.

Tairo, E.V., Ndakidemi, P.A., 2013. Bradyrhizobium japonicum inoculation and phosphorus supplementation on growth and chlorophyll accumulation in Soybean (Glycine max L.). Am. J. Plant Sci. 4, 2281-2289.

Tan, H., Barret, M., Mooij, M., Rice, O., Morrissey, J., Dobson, A., Griffiths, B., O'Gara, F., 2013. Long-term phosphorus fertilisation increased the diversity of the total bacterial community and the phoD phosphorus mineraliser group in pasture soils. Biol. Fertil. Soils 49, 661-672.

Tardy, V., Spor, A., Mathieu, O., Leveque, J., Terrat, S., Plassart, P., Regnier, T., Bardgett, R.D., van der Putten, W.M., Roggero, P.R., Seddaiu, G., Bagella, S., Lemanceau, P., Ranjard, L., Maron, P., 2015. Shifts in microbial diversity through land use intensity as drivers of carbon mineralization in soil. Soil Biol. Biochem. 90, 204-213.

Tilman, D., Cassmand, K.G., Matson, P.A., Naylor, R., Polasky, S., 2002. Agricultural sustainability and intensive production practices. Nature 418, 671-677.

Tunney, H., Kirwan, L., Fu, W., Culleton, N., Black, A.D., 2010. Long-term phosphorus grassland experiment for beef production - impacts on soil phosphorus levels and liveweight gains. Soil Use Manag. 26, 237-244.

Turner, B., Wright, J.S., 2014. The response of microbial biomass and hydrolytic enzymes to a decade of nitrogen, phosphorus, and potassium addition in a lowland tropical rain forest. Biogeochemistry 117, 115-130.

Wakelin, S., Mander, C., Gerard, E., Jansa, J., Erb, A., Young, S., Condron, L., O'Callaghan, M., 2012. Response of soil microbial communities to contrasted histories of phosphorus fertilisation in pastures. Appl. Soil Ecol. 61, 40-48.

Watanabe, F.S., Olsen, S.R., 1965. Test of an ascorbic acid method for determining phosphorus in water and $\mathrm{NaHCO}_{3}$ extracts from soil. Soil Sci. Soc. Am. J. 29, 677-678.

Will, C., Thümer, A., Wollherr, A., Nacke, H., Herold, N., Schrumpf, M., Gutknecht, J., Wubet, T., Buscot, F., Daniel, R., 2010. Horizon-specific bacterial community composition of German grassland soils, as revealed by pyrosequencing-based analysis of 16S rRNA genes. Appl. Environ. Microbiol. 76, 6751-6759.

Wu, J., Joergensen, R.G., Pommerening, B., Chaussod, R., Brookes, P.C., 1990. Measurement of soil microbial biomass $\mathrm{C}$ by fumigation-extraction—an automated procedure. Soil Biol. Biochem. 22, 1167-1169. 